E3S Web of Conferences 1, 02003 (2013)

DOI: $10.1051 / \mathrm{e} 3$ sconf $/ 20130102003$

(C) Owned by the authors, published by EDP Sciences, 2013

\title{
Contaminants in Sediments - Remediation and Management
}

\author{
$\underline{\text { A. S. Knox }}{ }^{1}$ and M. H. Paller ${ }^{1}$ \\ ${ }^{1}$ Savannah River National Laboratory, Aiken, SC 29808, USA, Phone: 803725 7021, Fax: 8037257673 , \\ anna.knox@srnl.doe.gov
}

\begin{abstract}
Metals and organic contaminants are common in many marine and fresh water environments as a result of industrial and military activities. Traditional remediation/risk management options for sediments contaminated with these materials include no action, monitored natural recovery, institutional controls (land use restrictions, etc.), in situ treatment and management, and ex situ treatment and management. Active capping is a newer approach for treating contaminated sediments that involves applying chemically reactive amendments to the sediment surface. The mobile, soluble forms of contaminants are generally considered toxic. Induced chemical precipitation of these metals can shift toxic metals from the aqueous phase to a solid, precipitated phase which is often less bioavailable. This can be achieved through the application of sequestering agents such as rock phosphates, organoclays, zeolites, clay minerals, and biopolymers (e.g., chitosan) in active caps. Active caps can stabilize contaminants in contaminated sediments, lower the bioavailable pool of contaminants, and reduce the release of contaminants to the water column thereby providing an economical and effective alternative to traditional treatments.
\end{abstract}

Key words: Passive caps, active caps, metals, sediments, in situ remediation, monitor natural recovery

\section{Introduction}

Water is a highly precious resource. More than half of the world's animal and plant species live in the water. Less than $5 \%$ is nonsaline (Yong, 2001), and only $0.2 \%$ and $0.3 \%$ are found in lake and rivers, respectively, and readily available for human use. Therefore, protection of water and sediment quality is highly important. Rapid industrialization and urbanization leads to the contamination of sediments with heavy metals and organic contaminants and creates a pervasive problem worldwide. Major sources of metal pollutants for the aquatic environment include agricultural and urban lands, industrial activities, spills, and accidents. In general, such pollutants enter the environment through surface runoff that discharges into rivers, lakes, and groundwater or through point sources from municipalities, industries, or other sources. These contaminants pose a potential risk to the environment and human health because they can harm aquatic organisms and enter aquatic food chains that lead to humans. Metals that enter the aquatic environment often accumulate in sediments that subsequently act as a source for contaminant remobilization. Metals, including $\mathrm{As}, \mathrm{Cd}, \mathrm{Cu}, \mathrm{Hg}, \mathrm{Ni}$, and $\mathrm{Pb}$ are often found in harbor sediments and other areas affected by anthropogenic activities.

\section{Discussion}

Management and Remediation of Contaminated Sediments

Current management and remedial options for contaminated sediments include no action, monitored natural recovery, institutional controls (land use restrictions, etc.), removal (dredging), in situ treatment and management, and ex situ treatment and management.

No action

"No action" is not equivalent to monitored natural recovery or natural attenuation. If no risk or minimal risk is determined from a risk assessment, then no feasibility study is needed and a no further action determination can be made at that point.

\section{Monitored natural recovery (MNR)}

Monitored natural recovery (MNR) is the reliance on natural processes to achieve remedial objectives. Natural attenuation processes include physical, chemical, or biological processes that act without human intervention 
to reduce the mass, toxicity, mobility, or concentration of contaminants (USEPA-ORD 1999). MNR is viable where the short-term risks posed by the contaminants are acceptable, the sediments are fairly stable, and the overall cost/benefit of MNR is desirable. The weaknesses of natural recovery are risk of changes in the site's natural processes, risk of contaminant dispersion due to natural or anthropogenic events, and risks posed by the current sediment concentrations/distribution until acceptable levels are achieved.

\section{Dredging}

Traditional efforts to manage contaminated sediments often focus on removal and ex-situ management including dredging or dry excavation followed by off-site management (including treatment) of the removed sediments. However, this method is relatively expensive and can mobilize contaminants and destroy benthic ecosystems. For example, in France more than $19 \mathrm{Mm}^{3}$ of sediment are dredged to maintain the Seine, Garonne, and Loire estuaries (Chamely, 2003). Dredged sediments, which often contain significant levels of contaminants, are either landfilled or ocean disposed where they can cause further problems. Most dredging has been limited to small sites $(<50,000$ cubic yards). The limitations of dredging include releases during implementation, risks to workers during construction and transportation, community impacts (accidents, noise, odor, air emissions), disruption of use and enjoyment of the resource, disruption of benthic ecology, impacts on fish and wildlife, impacts of contaminated residuals (inside and outside of the remedial area), and risk of releases at the final disposal location.

\section{In-situ management of contaminated sediments}

In-situ management of contaminated sediments is potentially less expensive and less risky than ex-situ management, but there are relatively few alternatives for in-situ treatment and some are still under development. Bioremediation, active capping, and passive capping are among the more promising alternatives for in situ sediment remediation.

\section{Bioremediation}

Bioremediation is the use of biological systems to remove or detoxify chemical pollutants in the environment. The goal of bioremediation is to degrade organic pollutants to concentrations that are either undetectable or, if detectable, to concentration below the limits established as acceptable by regulatory agencies. The complexity of sediment-water ecosystems often limits the effectiveness of in situ bioremediation, which is generally most successful when environmental conditions can be carefully controlled and adjusted as the biotransformation processes progress with time. However, such control is difficult to maintain under natural conditions. An example of bioremediation is the LIMNOFIX In Situ Treatment Technology (LIST) that was developed for the in situ remediation of contaminated sediments in fresh and marine water environments (Guo and Murphy, 2008). This technology is based on chemical formulations that include oxidants (calcium nitrate), binders, flocculants, and/or other amendments. (Guo and Murphy, 2008).

\section{Passive (inactive) capping}

Passive (inactive) capping is defined as the installation of a subaqueous covering or cap of clean, inert material over contaminated sediment, thus isolating it from the surrounding environment and reducing contaminant migration in the water phase. This alternative can be an effective approach for remediation of contaminated sediment under certain static conditions and is relatively economical. However, the inert materials (sand, gravel, or similar nonreactive materials) used in passive caps do not provide permanent stabilization since they are subject to leaching and mechanical disturbance that can release toxic contaminants (Figure 1). The application of passive caps also causes severe disruption and alteration of benthic ecology.

\section{Active capping}

In contrast to passive capping, active or reactive capping, which is targeted by the current proposal, involves the use of capping materials that react with sediment contaminants to reduce their toxicity or bioavailability. Active capping is a less mature technology that holds great potential for a relatively permanent solution that avoids residual risks resulting from contaminant migration through the cap or breaching of the cap. Active caps directly reduce the biological activity of sediment contaminants rather than simply making them less accessible. A selected set of active capping treatment technologies has been demonstrated at a few sites, including a field demonstration at the Savannah River Site, Aiken, SC (Knox et al., 2012) and the Anacostia Active Capping Demonstration Project (Reible et al., 2006). Knox et al.'s (2012) field deployment showed that active amendments such as apatite or organoclay can effectively immobilize contaminants but are subject to erosion in dynamic stream environments. It also provided useful information concerning the effects of sequestering agents on metal immobilization, bioavailability, toxicity, and resistance to mechanical disturbance.

\section{Active cap design}

The design of sediment caps must consider a wide variety of factors, including the mobility of the contaminants, burrowing habits of potential receptors, erosive forces acting on the surface of the cap, and 
geotechnical characteristics of the native sediment (Palermo et al., 1998).

In recent years, there has been considerable focus on capping amendments and active capping (Hawkins et al., 2006, Reible et al. 2006, Knox et al., 20011 a and b, Paller and Knox 2010, Dixon and Knox 2012). Specific amendments that have been evaluated include clays for permeability control, activated carbon, coke and organomodifed clay for organic contaminant sequestration and retardation, and phosphate minerals such as apatite for metals sorption and retardation. The control of metals can also be achieved through biogeochemical reduction in sediment as a result of cap placement. Activated carbon is an extremely effective organic contaminant sorption medium but is difficult to place due to density and is sensitive to fouling (Sharma, 2008). Placement of low density materials such as activated carbon has been proposed with mats (McDonough et al. 2007) and in formulations with other materials such as AquaBlok. Organo-modified clays are relatively easy to place in bulk or in mats and have the advantages of good resistance to fouling and substantial sorption capacity for non-aqueous phase liquids (Reible et al., 2007). Multiple amendment active caps (MAAC) offer the potential to economically treat a range of contaminants and can be combined with materials such as bentonite to improve resistance to erosion (Figure 1) (Knox et al., 2010 b)

\section{Conclusions}

Although problems remain, contaminated sediment management is improving. This paper provides a brief summary of the state of contaminated sediment management and remediation. Consideration of the current state-of-the-art suggests that there is a need for capping technologies that can sequester organic and inorganic sediment contaminants and create a reliable, stable, and long-lasting cap in a range of aquatic environments. Current technologies typically produce caps with limited physical stability that are suitable primarily for low-energy, depositional aquatic environments. However, depositional environments can become erosive as a result of unpredictable natural events such as floods and storms and anthropogenic actions such as boating and construction activities.

\section{References}

Chamely H. Geosciences, Environment and Man. Elsvier, Amsterdam, 2003.

Dixon KL, Knox AS. Sequestration of metals in active cap materials: A laboratory and numerical evaluation, Remediation: The Journal of Environmental Cleanup Costs, Technologies, \& Techniques, 2012; 22(2):81-91.

Guo J, MurphyT. Limno-fix in situ treatment. In Situ Contaminated Sediment Workshop, Cocordia University, Montreal, Quebec, March 10-11, 2008.

Hawkins AL, Tracey GA, Swanko JJ, Gardner KH, Melton JS. Reactive Capping Mat Development and

\section{Passive Cap \\ Layer of inert material \\ (e.g., sand) that isolates \\ contaminated \\ sediment from the surrounding environment}

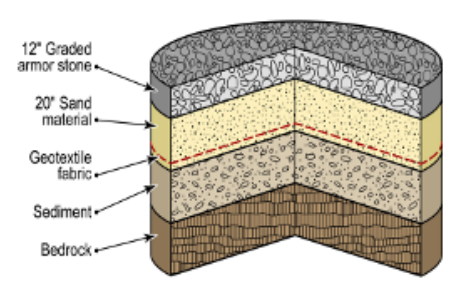

Problems:

$>$ Subject to transport of contaminants

$>$ Not a permanent solution

\section{Active Cap (single amendment) Reactive material that neutralizes or stabilizes contaminants in situ}

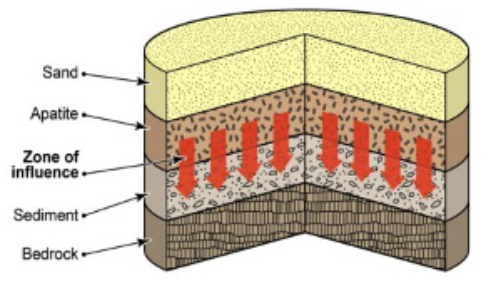

Problems:

$>$ Subject to erosion

$>$ Treats narrow range of contaminants

$>$ Could be toxic to benthic organisms unless diluted with other materials

\section{Multiple-Amendment Active Cap (MAAC Technology) A one-layer amendment mixture applied in one-step resulting in reduced costs and better remediation}

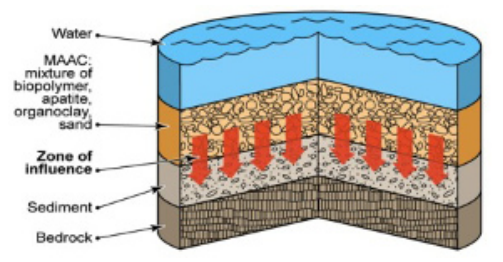

Benefits:

$>$ Treats broad range of contaminants

$>$ Nontoxic

$>$ Creates zone of influence

$>$ Erosion resistant

$>$ Can be mixed with natural substrates without loss of potency

Cost effective

Fig. 1. Development of capping technology (Knox et al., 2010 a and b) 
Evaluation for Sequestering Contaminants in Sediments, Final Report; ER-1493, DOD SERDP;Technical report TR-2366-ENV, 2011.

Knox AS, Paller MH, Dixon KL, Reible DD, Roberts J, Petrisor IG. Innovative in-situ remediation of contaminated sediments for simultaneous control of contamination and erosion. Final Report PART I, 2010a; SRNL-RP-2010-00480.

Knox AS, Paller MH, Dixon KL, Reible DD, Roberts J, Development of a multiple-amendment active cap (MAAC). 2010b; Final Report PART II, SRNL-RP2010-00480.

Knox AS, Paller MH, Roberts J, Active capping technology - new approaches for in situ remediation of contaminated sediments, Remediation: The Journal of Environmental Cleanup Costs, Technologies, \& Techniques, 2012; 22(2):93-117.

McDonough KM, Murphy P, Olsta J, Zhu Y, Reible DD, Lowry G. Development and Placement of a Sorbentamended Thin Layer Sediment Cap in the Anacostia River, J Soil \& Sediment Contamination 2007; 16:313-322.

Palermo MR, Maynord S; Miller J, Reible DD. Guidance for in-situ subaqueous capping of contaminated sediments. Chicago, Great Lakes National Program Office. 1998

Paller MH, Knox AS. Amendments for the remediation of contaminated sediments: Evaluation of potential environmental impacts. Sci. Total Environ.2010; 408:4894-4900.

Reible DD, Lampert D, Constant WD, Mutch RD, Zhu Y. Active Capping Demonstration in the Anacostia River, Washington, DC, Remediation: The Journal of Environmental Cleanup Costs, Technologies and Techniques, 2006; 17(1): 39-53.

Reible DD. Organoclay Core And Mat Laboratory StudyMcCormick And Baxter Creosoting Company, Portland, Oregon, Final Report to Oregon DEQ, 2007.

Sharma B. Evaluation of reactive cap sorbents for in-situ remediation of contaminated sediments, 2008; $\mathrm{PhD}$ Thesis, UNH.

USEPA-ORD. Monitored Natural Attenuation of Petroleum Hydrocarbons. Washington D.C.: Office of Research and Development, National Risk Management Research Laboratory, 1999; EPA/600/F-98/021. 